\title{
Materials for Polymer Electrolyte Fuel Cells
}

\author{
Lorenz Gubler ${ }^{a \star}$, Nina Beck ${ }^{\mathrm{a}}$, Selmiye Alkan Gürsela ${ }^{\mathrm{a}}$, Faegheh Hajbolouria ${ }^{\mathrm{a}}$, Denis Kramer ${ }^{\mathrm{a}}$, \\ Andreas Reiner ${ }^{a}$, Beat Steiger ${ }^{a}$, Günther G. Scherer ${ }^{a}$, Alexander Wokaun ${ }^{a}$, Bashyam Rajesh ${ }^{b}$, \\ and K. Ravindranathan Thampib
}

\begin{abstract}
The commercial success of the polymer electrolyte fuel cell (PEFC) will to a large extent be determined by the nature, properties, functionality, and cost of the electrochemical sub-components used in the membrane electrode assembly (MEA). Materials research activities in Switzerland for the PEFC are being pursued at the Paul Scherrer Institut (Villigen AG) and the Swiss Federal Institute of Technology in Lausanne with different objectives. The radiation grafted proton exchange membrane developed at the Paul Scherrer Institut (PSI) has been brought to a near-product-like quality level with encouraging performance close to state-of-the-art materials and a life-time of several thousand hours. Furthermore, the membrane shows low methanol crossover in the direct methanol fuel cell. In addition, polyarylene block copolymer membranes have been investigated as an option for fluorine-free membranes. The electrocatalysis of Pt in acidic solution and in contact with a solid electrolyte, the development of new methanol oxidation and oxygen reduction catalysts, and co-sputtering of $\mathrm{Pt}$ and carbon as an alternative method for catalyst preparation are areas of fundamental research. More applied research is performed in the characterization of commercial electrodes in single cells, using standard as well as advanced diagnostic tools developed in-house. This article gives an overview over the research and development projects in Switzerland related to materials and components for the PEFC.
\end{abstract}

Keywords: Direct methanol fuel cell · Electrocatalysis · Membrane electrode assembly ·

Polymer electrolyte fuel cell $\cdot$ Proton exchange membrane

\section{Introduction}

Among the various fuel cell types in existence, the polymer electrolyte fuel cell (PEFC) is a particularly promising technology for power generation in portable, stationary and mobile applications. Unlike in liquid electrolyte-based fuel cells, the cell components are solid materials and hence handling of hot and corrosive liquids can be avoided. The solid oxide fuel cell (SOFC) is

${ }^{*}$ Correspondence: Dr. L. Gublera

Tel.: +41563102673

Fax: +4156 3104416

E-Mail: Iorenz.gubler@psi.ch

aElectrochemistry Laboratory

Paul Scherrer Institut (PSI)

$\mathrm{CH}-5232$ Villigen PSI

bLaboratory of Photonics and Interfaces

ISIC-LPI

École Polytechnique Fédérale de Lausanne (EPFL)

$\mathrm{CH}-1015$ Lausanne also based on a solid electrolyte, yet the PEFC offers the advantage of rapid start-up due to its low operating temperature of up to $100{ }^{\circ} \mathrm{C}$. The SOFC, on the other hand, operating at a temperature of typically 700-1000 ${ }^{\circ} \mathrm{C}$, produces high quality waste heat, which can be further used in secondary processes.

The core component of the PEFC is the membrane electrode assembly (MEA), consisting of a solid proton exchange membrane (PEM) sandwiched between two porous carbon based gas diffusion electrodes (GDEs) (Fig. 1). The overall cell reaction is split into two half-cell reactions taking place at the anode-membrane and cathode-membrane interface, respectively, where a highly dispersed Pt or Pt alloy catalyst is deposited.

Fuel electrode (anode):

(1) $\mathrm{H}_{2} \rightarrow 2 \mathrm{H}^{+}+2 \mathrm{e}^{-}$ (hydrogen oxidation reaction, $\mathrm{HOR}$ )

(2) $\mathrm{CH}_{3} \mathrm{OH}+\mathrm{H}_{2} \mathrm{O} \rightarrow \mathrm{CO}_{2}+6 \mathrm{H}^{+}+6 \mathrm{e}^{-}$ (methanol oxidation reaction, MOR)

Air electrode (cathode):

(3) $1 / 2 \mathrm{O}_{2}+2 \mathrm{H}^{+}+2 \mathrm{e}^{-} \rightarrow \mathrm{H}_{2} \mathrm{O}$ (oxygen reduction reaction, $\mathrm{ORR}$ )
The fuel cell is a galvanic element, creating electricity by virtue of an electrochemical reaction of a fuel with an oxidant. Oxidation of the fuel releases electrons at the anode. $\mathrm{H}_{2}$ is the fuel of choice for most applications, as the $\mathrm{H}_{2}$ oxidation reaction (HOR, reaction 1) proceeds with high rate and low overpotential in the presence of $\mathrm{Pt}$ as electrocatalyst. $\mathrm{H}_{2}$ may be used in pure form, or in a gas mixture generated by reforming of a carbonaceous fuel, such as natural gas, gasoline, biomass, etc. ( $c f$. ' $\mathrm{Fu}$ els for Fuel Cells: Requirements and Fuel Processing' in this issue of CHIMIA [1]). In the direct methanol fuel cell (DMFC), methanol is used as fuel, which has the advantage of being liquid at room temperature and, therefore, having a higher energy storage density compared to hydrogen. The electrocatalysis of the methanol oxidation reaction (MOR, reaction 2) is much more sluggish compared to the HOR, leading to considerable anode polarization losses. In the $\mathrm{DMFC}, \mathrm{CO}_{2}$ is released from the anode. The electrons generated at the anode are conducted via an external circuit to the cathode, whereby they deliver electrical power to the consumer. In the PEFC, the ionic species exchanged between anode 


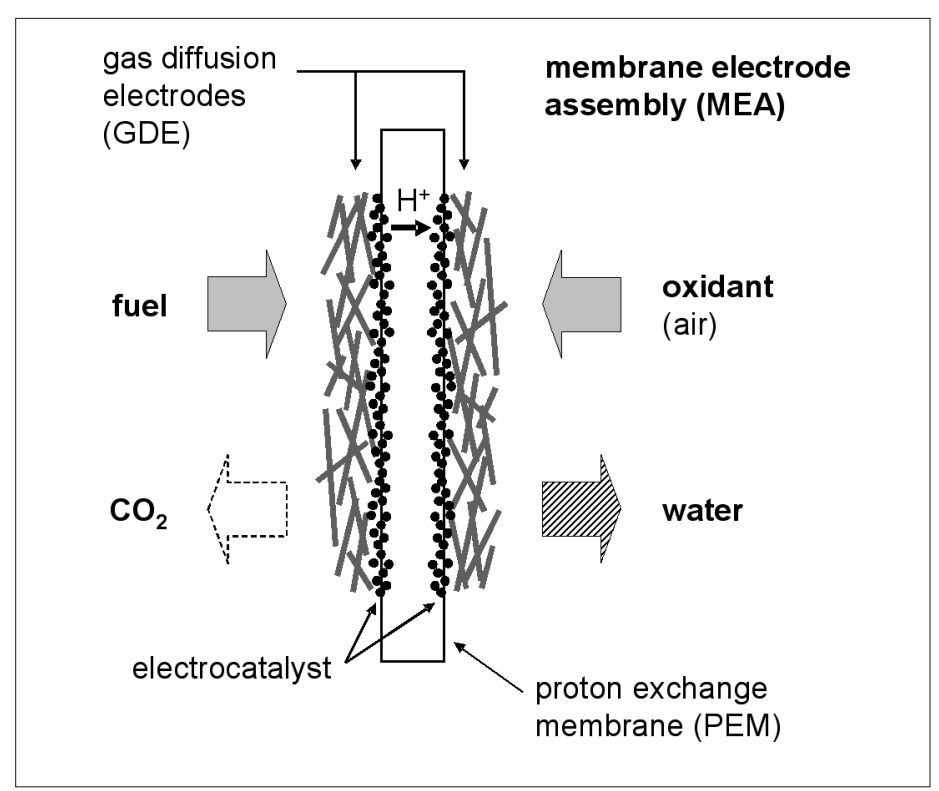

Fig. 1. Schematic of the basic electrochemical unit of the polymer electrolyte fuel cell (PEFC), the membrane electrode assembly (MEA). The fuel is oxidized at the anode. Electrons are transferred from anode to cathode via an external circuit (not shown), and protons are transported through the solid electrolyte membrane. At the cathode, oxygen is reduced and water is formed. If a carbonaceous fuel is used, $\mathrm{CO}_{2}$ is released at the anode.

and cathode are protons. Oxygen from air is used as oxidant in most cases. Water is formed as a product of the oxygen reduction reaction (ORR, reaction 3 ) at the cathode. The $\mathrm{H}_{2}$ /air cell has an open circuit voltage $(\mathrm{OCV})$ of around $1.0 \mathrm{~V}$, in the methanol/air cell around $0.8 \mathrm{~V}$ is obtained. A practical cell voltage during electric power generation is $0.7 \mathrm{~V}$ for $\mathrm{a}_{2}$ fueled cell, and $0.5 \mathrm{~V}$ for a methanol fueled cell. Typically, one cell delivers a power density of $0.5 \mathrm{~W} / \mathrm{cm}^{2}$ using $\mathrm{H}_{2}$ as fuel, and about $0.2 \mathrm{~W} / \mathrm{cm}^{2}$ in the DMFC.

The MEA has a thickness of around $0.5 \mathrm{~mm}$. Its subcomponents have different tasks and have to meet certain requirements in order for the MEA to function as expected. All the components of the MEA have to be chemically and mechanically stable and sufficiently resistant to corrosion and degradation in the environment of the PEFC.

The electrolyte membrane has to be mechanically robust and separate the half-cell reactions effectively to prevent direct reaction of fuel and oxidant and hot-spot formation. The required proton conductivity is of the order of $100 \mathrm{mS} / \mathrm{cm}$ at the operating temperature of the cell, which is 60 to $90{ }^{\circ} \mathrm{C}$ for the hydrogen fueled cell, and up to $120{ }^{\circ} \mathrm{C}$ for the DMFC. Proton exchange membranes (PEMs) are polymers in film form with a thickness between 20 and $200 \mu \mathrm{m}$ containing cation exchange sites. While the cations, e.g. protons, are mobile the anions are fixed to the polymer backbone. Consequently, the cation transference number is 1 . The majority of PEMs swell in water, and proton conductivity is strongly dependent on the water content of the membrane. The distribution of water within the membrane is therefore an important factor influencing the functioning of the fuel cell. The electrodes have to be electronically conducting and of porous structure, the latter to enable access of the reactants $\left(\mathrm{H}_{2}\right.$, methanol, $\mathrm{O}_{2}$ ) to the catalyst and removal of products $\left(\mathrm{H}_{2} \mathrm{O}, \mathrm{CO}_{2}\right)$. Gas diffusion electrodes (GDEs) are made of fibrous carbon material, such as cloths, papers or felts. The hydrophobicity of the GDE needs to be well designed by wet-proofing with PTFE to handle two-phase flows occurring in the $\mathrm{PEFC}$, i.e. air/liquid water on the cathode and $\mathrm{CO}_{2}$ /liquid water-methanol mixture on the anode of the DMFC. The catalyst layers, having a thickness of around $10 \mu \mathrm{m}$, contain Pt or Pt alloy electrocatalyst to promote the half-cell reactions. The catalyst loading is of the order of $0.1-1.0 \mathrm{mg} / \mathrm{cm}^{2}$. In order to maximize the surface of the catalyst, high surface area carbon (100-1'000 $\mathrm{m}^{2} / \mathrm{g}$ ) is used as catalyst support material. The resulting $\mathrm{Pt}$ particles have a diameter of around $2 \mathrm{~nm}$, corresponding to a dispersion of $50 \%$.

\section{Proton Exchange Membranes}

\subsection{Preparation of Radiation Grafted Membranes}

\subsubsection{Radiation Grafting: Approach}

Radiation-induced grafting is an attractive method to introduce desirable properties into a polymer owing to its simplicity in handling and control over the grafting process. This method offers the promise of polymerization of monomers that are difficult to polymerize by conventional methods without residues of initiators and catalysts. Moreover, polymerization can be carried out even at low temperatures unlike the polymerization with catalysts and initiators [2].

Radiation grafting involves the polymerization of a monomer into a preformed polymer film and leads to the formation of a branched structure, in which macromolecular chains of the base polymer film act as the backbone and the branches are side chains represented by the grafted moiety. The polymerization reaction is initiated by radicals generated by irradiation of the base polymer with an electron beam or $\gamma$-rays. There are three standard methods of radiation grafting: i) simultaneous method, in which the base polymer is irradiated in the presence of the monomer, resulting in the formation of active free radicals in both monomer and base polymer, ii) pre-irradiation method (trapped radicals), in which the base polymer is irradiated in vacuum or under an inert atmosphere to generate radicals prior to exposure to the monomer, iii) and pre-irradiation method (hydroperoxide method), in which the polymer is irradiated in the presence of air or oxygen to form mainly hydroperoxides which are decomposed at elevated temperature to initiate the grafting reaction (Scheme) [3].

Radiation grafting at PSI is performed preferentially by the pre-irradiation grafting method in air by exposing the base polymer film to an electron beam first and then immersing it in a solution containing monomer and cross-linker. Previously, $\gamma$-radiation in air was used for the pre-irradiation of the base polymer films; however, membranes produced by this method suffered from poor mechanical properties. Irradiation with electrons is preferred not only to enhance mechanical properties but also for shorter irradiation times, precise control of irradiation dose, and safer handling.

\subsubsection{Base Materials and Monomers}

Radiation grafting may be applied to a wide range of polymer-monomer combinations, such as various fluoropolymer films and acrylic and vinyl monomers. Styrene has been widely used as the monomer for this purpose since it is readily available and also the grafted styrene can be readily modified to introduce a variety of functionalities. Due to the known susceptibility of polystyrene towards oxidative degradation, the use of inherently more stable substituted styrene monomers is considered. For this purpose, studies on the monomer preparation and polymerization rate of $\alpha$-fluorostyrene, $\alpha, \beta, \beta$-tri- 


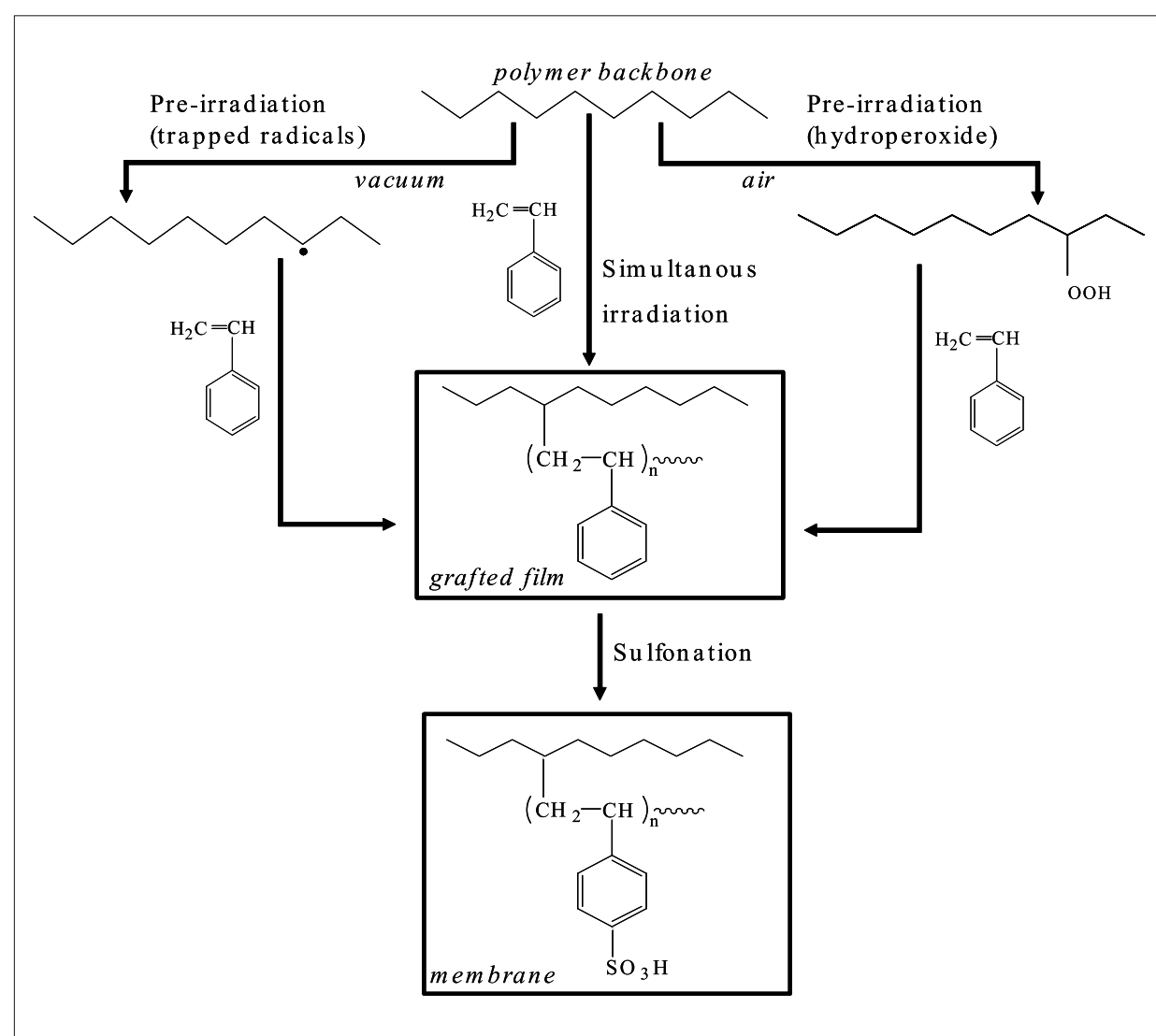

Scheme. Preparation routes for radiation grafted films and membranes

$$
\left[\mathrm{CF}-\mathrm{CF} \frac{]_{n}}{\mathrm{n}}\left[\mathrm{CF} \frac{\mathrm{CF}_{3}}{\mathrm{CF}}\right]_{\mathrm{m}}\right.
$$

FEP

poly(tetrafluoroethylene-co-hexafluoropropylene)

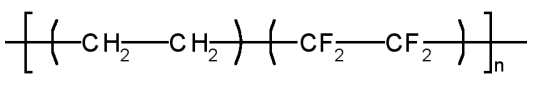

ETFE

poly(ethylene-alt-tetrafluoroethylene)

Fig. 2. Structure of the base polymers used for the preparation of radiation grafted membranes at PSI

flurostyrene and $o$-bromostyrene have been carried out [4]. However, radiation grafted films have not been prepared so far. Also, $\alpha$-methylstyrene is an interesting monomer in the context of chemical stability, and preliminary experiments using it as co-monomer with styrene for radiation grafting are in progress [5].

Partially fluorinated and perfluorinated polymers have been frequently used as base polymer to meet the requirements for chemically and thermally stable proton conducting membranes. Polytetrafluoroethylene (PTFE), poly(tetrafluoroethylene-co-hexafluoropropylene)

poly(ethylene-alt-tetrafluoroetylene)

(ETFE), poly(vinylidine fluoride) (PVDF), poly(tetrafluoroethylene-co-perfluorovinylether) (PFA), poly(vinylidine fluoride-co-hexafluropropylene) (PVDF-coHFP) have been used as host matrices for various graft copolymers. For the prepara- tion of radiation grafted proton exchange membranes at PSI, mainly FEP and ETFE have been used as base polymer and styrene as grafting component (Fig. 2) [6].

\subsubsection{Solvent System and Cross-linking}

The graft copolymerization reaction is carried out by bringing the activated base polymer film in contact with the monomer in liquid or vapor form. High yields and process efficiencies can be achieved using solution, emulsion, or suspension polymerization. According to the grafting front mechanism, grafting occurs initially at the surface of the film, then proceeds gradually inwards as the grafting zone is swollen by the monomer [7]. The type of solvent and the composition of the monomer/solvent mixture may influence the grafting kinetics, the length of grafted chains and polymer microstructure. Benzene, toluene and dichloromethane, alcohols, in particular methanol, ethanol or propanol, have been used as solvents for radiation grafting of styrene and styrene derivatives. It was found that polar solvents are generally favorable solvents for pre-irradiation grafting [8].

Cross-linkers are used in conjunction with the monomer to achieve certain desirable properties in a grafted membrane. Cross-linking agents such as divinylbenzene (DVB) may be introduced into the grafting solution. These are monomers with two or more vinyl groups, such that the grafted polymer chains are bridged and linked together, as a consequence of which the tensile modulus and strength of the material increase, whereas the swelling and toughness decrease [9-11]. Radiation grafted membranes cross-linked with DVB show lower surface energy and hydrophilicity, which influences the membrane-electrode interface in the resulting MEA [12][13]. Another drawback of the use of cross-linkers is that they may enhance the rate of homopolymerization [14].

Cross-linkers may increase or decrease the grafting yield depending on their concentration. At low concentration of the cross-linker the increased degree of grafting is attributed to the enhanced number of branching reactions. At high concentration of the cross-linker, on the other hand, a network structure, which causes a suppression in the swelling of the graft and an increase in viscosity of the grafting solution, is formed. That further leads to a decrease in the diffusion and availability of the monomer and, consequently, grafting yield is found to be lower [14]. The higher 'structural density' of cross-linked membranes significantly improves the chemical stability of FEP and ETFE based membranes [15].

\subsubsection{Sulfonation}

The graft copolymer film, consisting of the base polymer onto which polystyrene side chains have been polymerized, is not a fuel cell membrane yet, it lacks proton conductivity. Sulfonation of the phenyl groups, which introduces sulfonic acid sites, makes the polymer hydrophilic and swellable in water. The acid dissociates in the presence of water, and the resulting mobility of the proton provides the ionic conductivity of the membrane. Sulfonation is generally carried out using chlorosulfonic acid. In our laboratory, the grafted films are sulfonated with 2 vol-\% chlorosulfonic acid in $\mathrm{CH}_{2} \mathrm{Cl}_{2}$ at room temperature for $5 \mathrm{~h}$, followed by hydrolysis and re-acidification to obtain the $-\mathrm{SO}_{3} \mathrm{H}$ functional group [16]. Typically, the degree of sulfonation achieved is around 95\%, complete sulfonation of $100 \%$ corresponding to one sulfonic acid group per phenyl ring. 


\subsection{In Situ Characterization of Radiation Grafted Membranes}

Characterization of radiation grafted and sulfonated membranes in single cells has been performed from the very beginning of the project in 1992. Base polymers used were FEP and ETFE in thicknesses ranging from 25 to 125 microns. Membranes based on thin $(25 \mu \mathrm{m})$ FEP and ETFE film can be prepared such that single cell performance identical to $\mathrm{Nafion}^{\circledR} 112$ can be achieved [17]. The cell performance characteristics strongly depend on the membrane properties, especially the proton conductivity. For radiation grafted membranes, the conductivity is governed to a large extent by the amount of grafted component, which contains the ionic sites. Higher levels of grafting yield a higher conductivity, yet the chemical stability of the membrane decreases, because the grafted polystyrene side chains are more prone to chemical attack in the fuel cell environment. Furthermore, the mechanical properties of the membrane deteriorate with graft level due to the increasing brittleness of the material [8].

It has been recognized early that crosslinking of the grafted polystyrene is of paramount importance for several reasons [9]. Firstly, cross-linking using divinylbenzene (DVB) as co-monomer reduces gas transport across the membrane, as evidenced by the open circuit voltage (OCV) in a cell [15]. This can be explained by a higher compactness (lower swelling) of the crosslinked polystyrene domains. At the same time, membrane degradation, expressed as increase in membrane resistance with time, is lowered. However, cross-linking also leads to undesirable higher membrane resistance, because less water is present within the structure of the polymer to assist proton transport

In an MEA, the interface between membrane and electrodes can contribute substantially to efficiency losses. Polystyrene grafted membranes cross-linked with DVB were found to have a considerably lower surface energy compared to perfluorinated membranes of the Nafion ${ }^{\circledR}$ type, at all water content values investigated [12]. This means that the membranes are more hydrophobic, which may be an explanation for the poor membrane-electrode interface in MEAs with cross-linked radiation grafted membranes [18]. Uncrosslinked membranes, on the other hand, have surface energies comparable to those of perfluorinated membranes. Characterization of the membrane surface using photoelectron spectroscopy indicates that as the concentration of DVB is increased, the amount of sulfonated polystyrene, i.e. the hydrophilic component of the membrane, was found to decrease, rendering the membrane surface more hydrophobic [19]. Furthermore, the

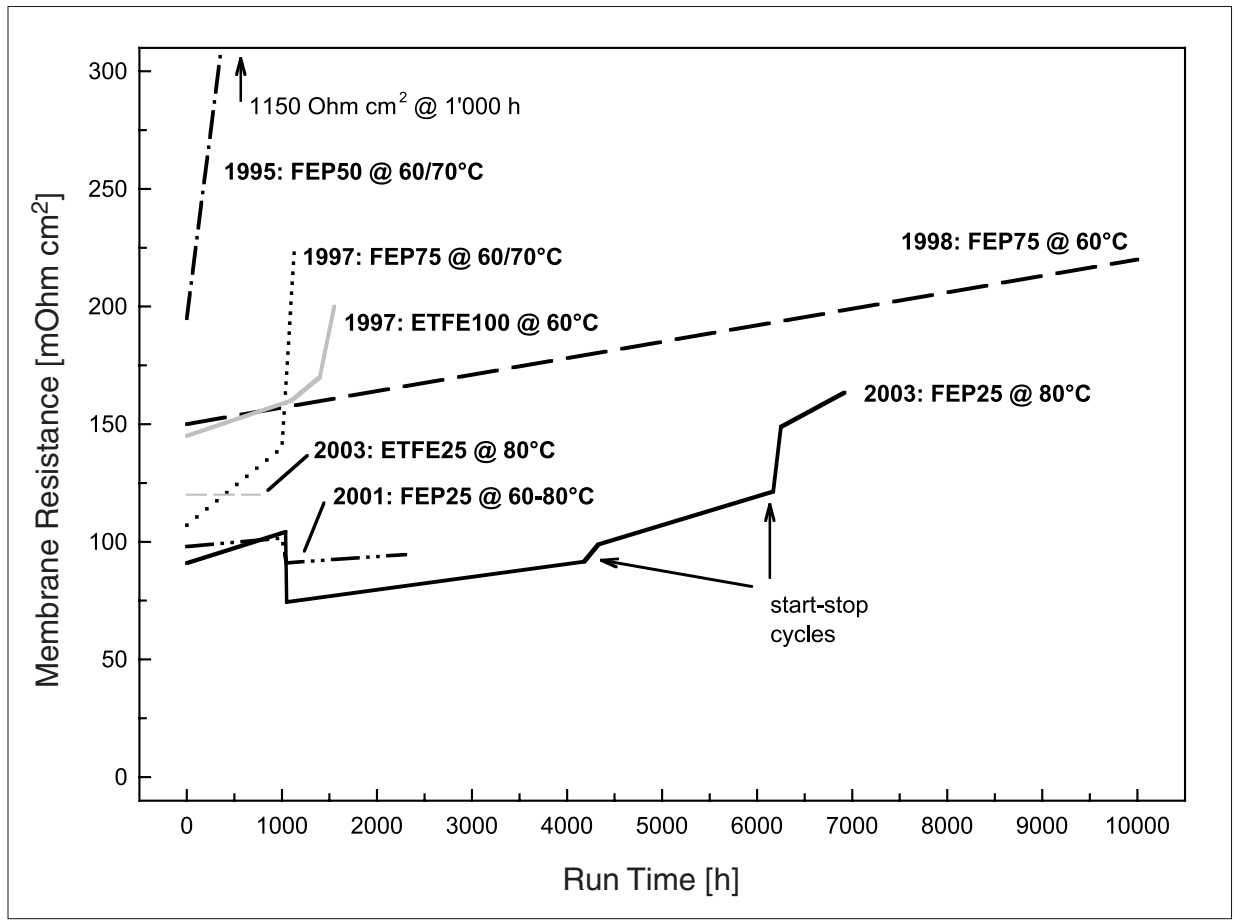

Fig. 3. Evolution of performance and durability of radiation grafted membranes developed at PSI, expressed as membrane area resistance. The graph represents in situ data, recorded during single cell experiments using the current pulse method [17].

degree of cross-linking appears to be higher at near surface regions of the membrane [20]. Due to these findings, it is deemed essential to increase the hydrophilicity of the crosslinked membranes and optimize the MEA laminating conditions to obtain a membrane-electrode interface with low impedance. In a recent study, we found that the modification of the membrane surface by coating with solubilized Nafion ${ }^{\circledR}$, as well as hotpressing the membrane in waterswollen state results in improved interface characteristics, i.e. lower impedance, yielding superior fuel cell performance [13][21].

In addition to performance, durability of fuel cell components is crucial to the viability of the technology. Initially, our radiation grafted membranes deteriorated rapidly within a few 100 hours of operation (Fig. 3) [15]. Subsequently, the membrane preparation as well as the MEA fabrication process and single cell hardware was optimized, which resulted in a markedly improved durability, even at a lower membrane thickness and higher operating temperature. The most important improvements were:

- Using electron instead of gamma radiation, resulting in less radiation damage of the base film [22].

- Enhanced grafting kinetics by using an alternative solvent system, which permitted us to decrease the irradiation dose by an order of magnitude [8].

- Using a lower graft level for improved mechanical and chemical stability [8][23].
The latest data show stable operation of an FEP $(25 \mu \mathrm{m})$ based membrane at high performance and low membrane resistance of less than $100 \mathrm{mOhm} \mathrm{cm}^{2}$ over several thousand hours, at a cell temperature of 80 ${ }^{\circ} \mathrm{C}$ [13]. Sharp increases in membrane resistance at $4200 \mathrm{~h}$ and $6200 \mathrm{~h}$ can be correlated with adverse start-stop cycles of the cell (e.g. test facility power outages), which resulted in accelerated degradation of fuel cell components, both membrane and electrodes.

\subsection{Radiation Grafted Membranes for the DMFC}

The supply of a methanol/water mixture to the anode of the DMFC, which distinguishes the DMFC from the hydrogen-fueled PEFC, bears many implications regarding desirable materials properties of MEA components. Mainly the anode and the membrane are subject to materials development for two reasons: i) the electrooxidation of methanol; reaction (2), is a complex multi-step, multi-pathway reaction, resulting in considerably higher voltage losses compared to the electrooxidation of hydrogen, reaction (1), and ii) commercial polymer electrolytes, such as Nafion ${ }^{\circledR}$, possess considerable permeability for methanol (and water) and therefore only partially fulfill the requirement to separate anodic and cathodic reactants from each other. The crossover of methanol through the membrane from anode to cathode impairs the performance of a DMFC in two ways: i) the fuel efficiency is significantly 
reduced, because the permeated methanol is consumed by getting oxidized at the platinum loaded cathode, and ii) the concomitant formation of a mixed cathode potential is detrimental to the cell voltage.

Based on PSI's development of radiation grafted membranes for the PEFC, this versatile technique has been adopted to fabricate membranes tailored to the requirements of the DMFC with the aim of reducing the methanol crossover, while retaining the electrical performance, compared to the $175 \mu \mathrm{m}$ thick commercial standard electrolyte Nafion ${ }^{\circledR} 117$ [24][25]. Results show that with a $75 \mu \mathrm{m}$ FEP based membrane, which has a thickness of around $90 \mu \mathrm{m}$ after grafting and sulfonation, being still only half the thickness of Nafion ${ }^{\circledR} 117$, performance comparable to Nafion ${ }^{\circledR} 117$ is obtained, yet with significantly lower methanol permeation rate, in particular at low current densities (Fig. 4). The cell performance using $25 \mu \mathrm{m}$ FEP based membrane is even better, yet without the benefit of lower methanol crossover. Another important finding was that the radiation grafted membranes fabricated for the DMFC show lower water permeation compared to Nafion ${ }^{\circledR} 117$, which allows cell operation at lower air stoichiometry (2.0 instead of 5.0) due to reduced accumulation of liquid water in the cathode gas diffusion medium, enhancing thereby the accessibility of the cathode for oxygen. The lower air stoichiometry has a positive effect on the overall efficiency of the DMFC due to lower parasitic power consumption for the air supply.

The performance achieved so far in combination with the proven durability - no serious degradation has been observed over $600 \mathrm{~h}$ of operation for an FEP $25 \mu \mathrm{m}$ based membrane at a cell temperature between 90 and $110{ }^{\circ} \mathrm{C}$ - is encouraging to further pursue the application of radiation grafted membranes in DMFC. Forthcoming investigations will focus on ETFE as base polymer. Enhanced diagnostics ( $c f$. 'Test and Measurement Methods for Fuel Cell Technology' in this issue of CHIMIA [26]) will provide a deeper insight into the DMFC and foster the tailoring of MEA components, such as radiation grafted membranes and novel methanol oxidation catalysts.

\subsection{Fluorine Free Membrane Materials}

A very limited number of non-fluorinated polymer backbone types have a chance to withstand the extremely demanding conditions a fuel cell membrane is exposed to. Hydrolysis, oxidation, reduction (hydrogenation), and radical reactions can lead to degradation of the polymer, thus reducing the lifetime of the polymer electrolyte membrane. Aromatic polyethers are among the first choice for this application.

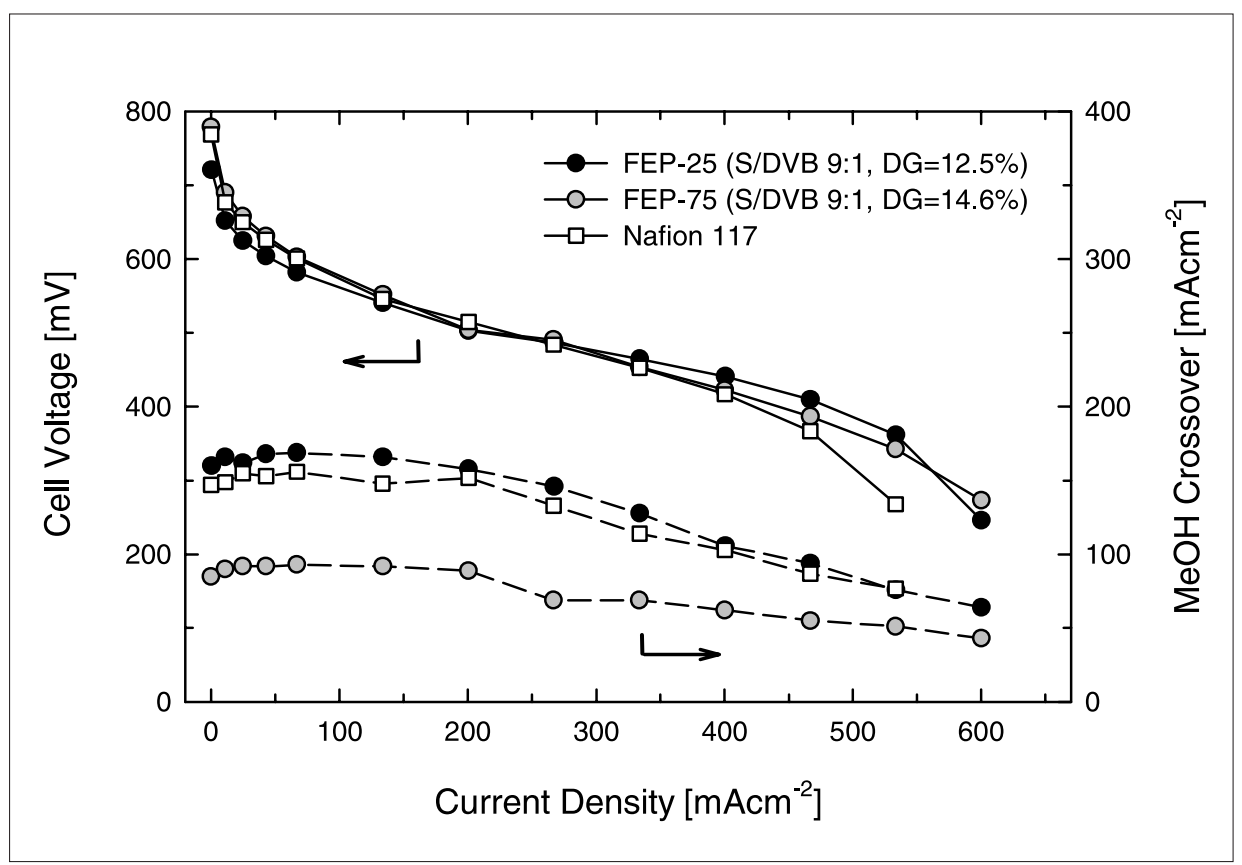

Fig. 4. Comparison of the single cell performance and methanol crossover of radiation grafted membranes based on FEP with different thickness with commercial Nafion ${ }^{\circledR}$ 117. Electrodes: anode Pt$\mathrm{Ru} / \mathrm{C} 1.0 \mathrm{mg}_{\mathrm{Pt}} \mathrm{cm}^{-2}$, cathode Pt black $4.0 \mathrm{mg}_{\mathrm{Pt}} \mathrm{cm}^{-2}$. Cell temperature $110{ }^{\circ} \mathrm{C}$, pressure 3 bar $_{\mathrm{a}}$, $12 \mathrm{ml} / \mathrm{min} 0.5 \mathrm{M}$ methanol, air stoichiometry is 2.0 for FEP and 3.0 for Nafion ${ }^{\circledR} 117$.
Poly(arylene ether)s, especially poly(ether ketone)s and poly(ether sulfone)s, are very promising candidates for future improvements. Besides their chemical stability, these polymer classes also exhibit excellent mechanical properties in their native forms. Sulfonation of these types of polymers has been attempted successfully already. However, post sulfonation of preformed polymers offers only limited control over the position, number, and distribution of the sulfonic acid groups along the polymer backbone or requires indirect routes via reactive intermediates. Thus, in a collaboration between PSI and the 'Lehrstuhl für Makromolekulare Stoffe' at the Technical University Munich, Germany, we chose a different, more suitable approach. The sulfonic acid groups were introduced into the monomers. Sulfonated aromatic ether ketone monomers were polymerized by adaptation of established procedures, which allowed improved control over the polymer structure [27]. The obtained polymers exhibit high molar masses with weight average molecular weights of up to $1.84 \cdot 10^{5} \mathrm{gmol}^{-1}$. The acid functionalized polymers exhibit acceptable thermal stability, i.e. a 5\% weight loss occurring between 310 and $324{ }^{\circ} \mathrm{C}$ in TGA under synthetic air. The mechanical properties of these polymers indicate ductile mechanical behavior with an elongation at break up to $230 \%$. The water uptake of films cast from the polymers are between 39 and $49 \mathrm{wt}-\%$, which corresponds to 8.8 to 10.0 molecules of $\mathrm{H}_{2} \mathrm{O}$ per sulfonic acid group. In practice, however, these films were difficult to handle as solid electrolyte for fuel cell applications.

In a subsequent set of experiments, utilizing essentially the same chemistry, block copolymer ionomers fully based on hydrocarbons were synthesized successfully using a two-stage process: first the hydrophobic block was prepared with the desired length, then the monomers for the hydrophilic block were added at the desired stoichiometry to adjust the length. Thus, each block copolymer ionomer consists of an alternating sequence of several hydrophobic and hydrophilic blocks (Fig. 5). A range of block copolymer ionomers having different ion exchange capacity were prepared successfully by varying the stoi-

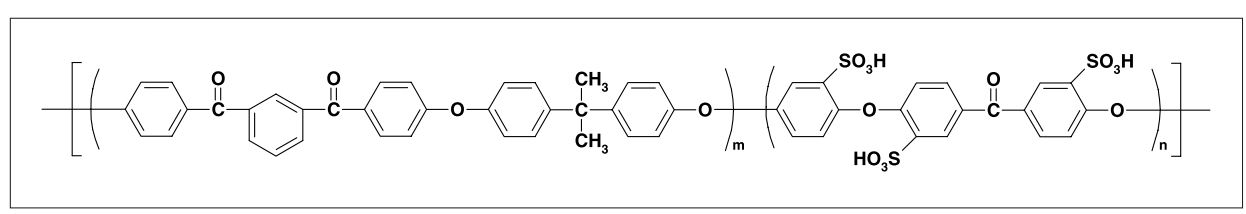

Fig. 5. Example for the chemical structure of a fluorine-free block copolymer used as a fuel cell membrane. A hydrophobic block (left) offering mechanical integrity of the membrane, a hydrophilic block (right) providing proton conductivity. 
chiometry of the monomers. This approach provided a novel route for preparing polymer electrolytes comprising an alternating sequence of hydrophobic non-sulfonated and hydrophilic sulfonated blocks [28]. The proton conductivity of these membranes was simultaneously dependant on the ion exchange capacity, the volume fraction of hydrophilic blocks, and the degree of sulfonation in the hydrophilic blocks. Conductivity increased with increasing ion exchange capacity and volume fraction of hydrophilic blocks in the same series. For example, a block copolymer containing hydrophobic blocks with molar mass (number average) of 2'400 g/mol and hydrophilic blocks with 5'100 g/mol, respectively, exhibited an ion exchange capacity of $1.5 \mathrm{mmol} / \mathrm{g}$ and a conductivity of $81 \mathrm{mS} / \mathrm{cm}$ at room temperature (Nafion ${ }^{\circledR}$ 112: $\left.82 \mathrm{mS} / \mathrm{cm}^{2}\right)$. As for the mechanical properties, these membranes show high yield stress and tensile strength (up to 88 $\mathrm{MPa}$ and $80 \mathrm{MPa}$, respectively) with an elongation at break of up to $290 \%$. The material is insoluble in organic solvents as well as in boiling deionized water in its acid form. Preliminary fuel cell tests using these block copolymer membranes showed good stability as well as acceptable performance compared to Nafion ${ }^{\circledR}$ membranes of similar thickness.

\section{Electrocatalysis}

\subsection{Aspects of Pt Utilization}

The catalyst in state-of-the-art MEAs consists predominantly of Pt nanoparticles supported on high surface area carbon. In order for the reaction to proceed on the catalyst, it has to be connected to the electrolyte phase. The co-existence of electronic, ionic and gas phase is required, which is realized in the triple phase boundary of the anode and cathode catalyst layer, respectively (Fig. 6). In the absence of ionomer in the catalyst layer, only the catalyst particles in direct contact with the membrane are electrochemically active. Impregnation of the catalyst layer with ionomer leads to an increase in the electrochemically accessible Pt by an order of magnitude, as evidenced by cyclic voltammetry (CV) [29][30]. The impregnation produces a thin film of solid electrolyte, which forms a proton-conducting bridge between the membrane and those Pt particles that are not in direct contact with the membrane. There is a limit to the amount of ionomer that can be introduced into the catalyst layer before adversely affecting the performance of the PEFC by blocking the access of reactant. We explored alternative methods for providing proton conductivity in the catalyst layer by chemical modification of carbon surfaces with sulfonic acid groups [31][32].

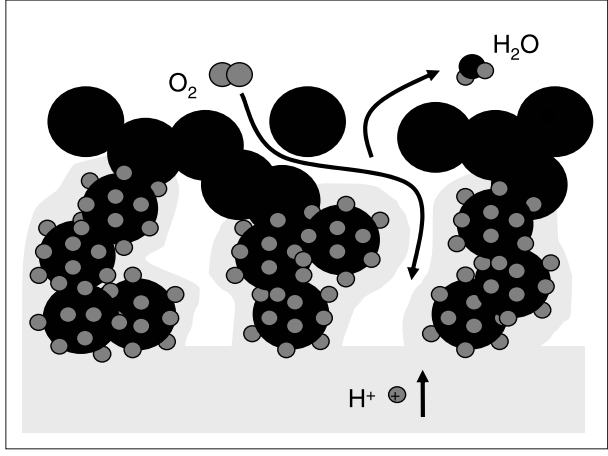

Fig. 6. Catalyst layer of the PEFC, configured as a triple phase boundary at the membrane-electrode interface, with co-existing electronic (carbon and catalyst), ionic (proton conducting polymer, e.g. Nafion ${ }^{\circledR}$ ) and gas phase (porosity). The cathode reaction, the reduction of oxygen and formation of water, is shown for illustration.

A central aspect in our efforts to understand Pt utilization at the electrode/solid polymer electrolyte interface has been the development of a model system for GDEs. Model electrodes were prepared by microstructuring the surface of glassy carbon plates into comb-like structures (depths of 100-150 $\mu \mathrm{m})$ using a rotating blade microsaw (widths of $15-50 \mu \mathrm{m}$ ) and covering these lamellae with $\mathrm{Pt}$ using different configurations [29][31][33][34]. Complex microstructures (e.g. serpentine pattern with round corners) can be fabricated by a novel process that combines laser structuring of a metal mask with subsequent reactive ion etching [35]. We were able to observe similarities with regard to the Pt surface utilization in GDEs and microstructured model electrodes in contact with Nafion ${ }^{\circledR} 117$ using the voltammetric method of underpotential deposition of hydrogen $\left(\mathrm{H}_{\text {upd }}\right)$. Contrary to GDEs, the defined surface geometry and Pt distribution pattern of the model electrodes allowed us to identify mechanistic scenarios describing Pt surface utilization [34].

With the intention of establishing a baseline for the $\mathrm{H}_{\text {upd }}$ behavior of $\mathrm{Pt}$, we also examine polycrystalline Pt disk electrodes in $0.5 \mathrm{M} \mathrm{H}_{2} \mathrm{SO}_{4}$. It was discovered early that the $\mathrm{CV}$ of a Pt electrode in $0.5 \mathrm{M}$ $\mathrm{H}_{2} \mathrm{SO}_{4}$ is quite similar to the $\mathrm{CV}$ of $\mathrm{Pt}$ in contact with a Nafion ${ }^{\circledR}$ membrane [36]. Polycrystalline $\mathrm{Pt}$ in $0.5 \mathrm{M} \mathrm{H}_{2} \mathrm{SO}_{4}$, as observed by $\mathrm{CV}$, shows deposition of atomic hydrogen in the form of well-resolved peaks (underpotential deposition, $\mathrm{H}_{\text {upd }}$ ) before the onset of hydrogen gas evolution. The area defined by the $\mathrm{H}_{\text {upd }} \mathrm{CV}$-peaks (after subtraction of the area corresponding to the response of the double layer) can be used to determine the number of Pt surface atoms. This procedure is especially widely applied for the determination of the surface roughness, $r_{f}$, for many types of Pt elec- trodes, in particular to determine the electrochemical Pt surface area in MEAs.

In addition to $\mathrm{CV}$ methods, ac impedance spectroscopy offers interesting possibilities for the investigation of the described interfaces, also with regard to the $\mathrm{H}_{\text {upd }}$ process. Preliminary impedance measurements [37][38] showed that it is necessary to establish a stable electrochemical active surface in the potential region where the $\mathrm{H}_{\text {upd }}$ process takes place. We demonstrated that the surface morphology has an influence on the stability of the $\mathrm{H}_{\text {upd }}$ area over time, which is for example affected by organic impurities [39]. Such impurities are inevitable when using polymer membranes as electrolyte.

To gain insight into the effect of electrode configuration and morphology on the stability as a function of time, different types of Pt electrodes were characterized in a half-cell setup (Table 1) and the active $\mathrm{Pt}$ surface was measured as a function of time (Fig. 7). Contrary to the behavior of the flat Pt disk electrode (E-1), the roughened $\mathrm{Pt}$ disk electrode (E-2) shows a quite stable electrochemically active surface, expressed in terms of $\mathrm{H}_{\text {upd }}$ area. To clarify whether or not the increased absolute surface area (because of roughening) or the morphological aspect is the reason for this stability, the measurement was repeated with a mesh type Pt electrode (E-3). Like E-1 the mesh electrode showed a decrease in $\mathrm{H}_{\text {upd }}$ area. E-3 has a much larger surface than E-2, therefore the roughness is mainly responsible for the stable $\mathrm{H}_{\text {upd }}$ area of E-2. Using such electrodes, it should in principle be possible to carry out ac impedance measurements that require stable surface conditions in the $\mathrm{H}_{\text {upd }}$ region and gain more information about the electrode/solid polymer electrolyte interface.

\subsection{Novel Methanol Oxidation Catalysts}

In a close collaboration between the École Polytechnique Fédérale de Lausanne (EPFL), and the Indian Institute of Technology (Prof. B. Viswanathan's group), Madras, India, various catalytic systems based on nanostructured carbon, conducting polymers, and nanocomposites of conducting polymers and transition metal oxides were developed as anode material for methanol oxidation. The carbon nanotubules [40-42], conducting nanocomposites of polyaniline [43] and conducting nanotubules of polypyrrole [44], and conducting polymeric nanocones [43][45] of poly(3-methyl)thiophene (PMT) have been synthesized by a template method. The catalytic activity of Pt$\mathrm{WO}_{3}$, Pt-Ru and Pt nanoparticles loaded carbon nanotubes has been evaluated as electrode material for methanol oxidation in the half-cell mode (using aqueous sulfuric acid 
as the electrolyte) and has been compared with commercial catalysts [41-44]. For the first time, the conducting polymeric nanotubules [44] and nanocones [43] were synthesized on carbon cloth and loaded with $\mathrm{Pt}$ nanoparticles to investigate the morphology by techniques such as SEM, HR-TEM, XPS, $\mathrm{XRD}$, TGA and evaluate the electrocatalytic activity for methanol oxidation [45] via cyclic voltammetry (CV) and electrochemical impedance spectroscopy (EIS). The intercalated nanocomposite system based on conducting polyaniline and $\mathrm{V}_{2} \mathrm{O}_{5}$ has been used to support catalytic active Pt particles for methanol oxidation [43]. Some of the above-mentioned materials exhibited excellent catalytic activity for methanol oxidation and stability at room temperature in comparison to the conventional and commercial materials.

The methanol oxidation activity has been measured as a function of Pt loading on template-synthesized PMT (Fig. 8). It was found that the methanol oxidation current density for the templated nanocone electrode at $+0.6 \mathrm{~V}$ vs. $\mathrm{Ag} / \mathrm{AgCl}$ reference electrode increased from $25 \mathrm{~mA} / \mathrm{cm}^{2}(20$ $\left.\mu \mathrm{g}_{\mathrm{Pt}} / \mathrm{cm}^{2}\right)$ to $290.6 \mathrm{~mA} / \mathrm{cm}^{2}\left(90 \mu \mathrm{g}_{\mathrm{Pt}} / \mathrm{cm}^{2}\right)$. For the commercial E-TEK 20 wt- $\%$ $\mathrm{Pt} /$ Vulcan electrode (figure not shown), it increased from $12 \mathrm{~mA} / \mathrm{cm}^{2}\left(20 \mu \mathrm{g}_{\mathrm{Pt}} / \mathrm{cm}^{2}\right)$ to $176 \mathrm{~mA} / \mathrm{cm}^{2}\left(150 \mu \mathrm{g}_{\mathrm{Pt}} / \mathrm{cm}^{2}\right)$, and for the conventional PMT electrode the activity increased from 7.2 to $20.4 \mathrm{~mA} / \mathrm{cm}^{2}$ only, for Pt loadings of 20 and $80 \mu \mathrm{g}_{\mathrm{Pt}} / \mathrm{cm}^{2}$, respectively. The inset of Fig. 8 shows a transmission electron microscope image of PMT nanocones synthesized by the template method. The stability of the PMT nanocone electrodes has been compared with commercial E-TEK catalyst and with the conventional PMT electrodes by measuring the chronoamperometric response of the electrodes at $+0.6 \mathrm{~V} v s$. $\mathrm{Ag} / \mathrm{AgCl}$. The percentage decrease of the catalytic activity of the nanocone electrode was $14.3 \%$ at the end of $2 \mathrm{~h}$, whereas the corresponding decrease was $25 \%$ for $20 \mathrm{wt}-\% \mathrm{Pt} / \mathrm{C}$ (E-TEK), and $44.6 \%$ for the conventional PMT electrode. The initial activity of the nanocone electrode is higher by nearly 12 times compared to the conventional PMT electrode and 2.5 times higher compared to $20 \mathrm{wt}-\% \mathrm{Pt} / \mathrm{C}$ (E-TEK) electrodes. The Pt loading was 80 $\mu \mathrm{g} / \mathrm{cm}^{2}$ for all the electrodes. In order to make the next step in developing novel catalysts for fuel cell application, it is desirable to employ these promising materials in DMFC and PEFC, where proton exchange membranes are used as electrolyte.

\subsection{CO and Reformate Tolerance}

$\mathrm{CO}$ poisoning of the anode electrocatalyst is a main problem in PEFCs operating with $\mathrm{H}_{2}$ derived from reformed hydrocarbon fuel. In addition to $\mathrm{H}_{2}$, the reformate

Table 1. Half-cell characterization of different Pt electrodes in $0.5 \mathrm{M} \mathrm{H}_{2} \mathrm{SO}_{4}$ at room temperature.

$\begin{array}{llll}\text { Electrode type } & \text { Label } & \begin{array}{l}\text { Electrochemical active } \\ \text { surface } A\left[\mathrm{~cm}^{2}{ }_{\mathrm{Pt}}\right]\end{array} & \begin{array}{l}\text { Roughness factor } r_{f} \\ {\left[\mathrm{~cm}^{2}{ }_{\mathrm{Pt}} / \mathrm{cm}^{2}{ }_{\text {geom. }}\right]}\end{array} \\ \text { flat Pt disk } & \mathrm{E}-1 & 0.00083 & 1.7 \\ \text { roughened Pt disk } & \mathrm{E}-2 & 0.01078 & 22 \\ \text { Pt mesh } & \mathrm{E}-3 & 16.6 & 2.4\end{array}$

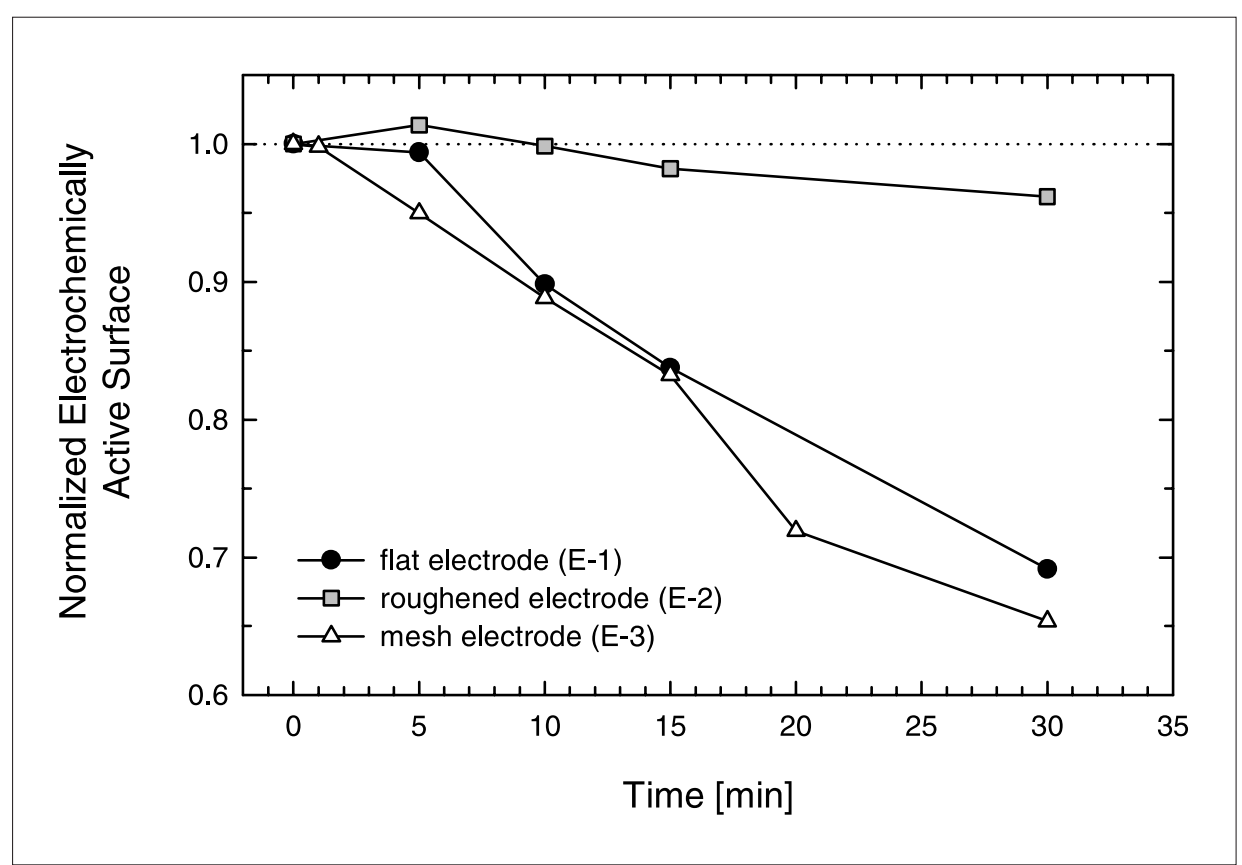

Fig. 7. Stability of the electrochemically active surface for the different electrode types characterized in Table 1 as a function of time

gas stream contains $\mathrm{CO}_{2}$ in the range of 20\%, 10-1000 ppm CO after cleanup, and around $40 \% \mathrm{~N}_{2}$, the exact composition depending on the particular fuel reforming process. At the typical operating temperature of the PEFC of around $80{ }^{\circ} \mathrm{C}$, the $\mathrm{CO}$ strongly adsorbs on the $\mathrm{Pt}$ and forms a near to complete monolayer, thereby blocking the access of $\mathrm{H}_{2}$, resulting in a large anode overpotential. One of the challenges is to optimize the fuel cell operating conditions and the MEA design to tolerate the maximum possible $\mathrm{CO}$ concentration, i.e. at least $100 \mathrm{ppm} \mathrm{CO}$. The approaches to diminish the effect of $\mathrm{CO}$ poisoning are i) the use of a CO tolerant anode electrode [46], ii) increase of the cell temperature [47] and iii) injection of a small amount of $\mathrm{O}_{2}$ or air into the fuel, so-called $\mathrm{O}_{2}$ - or air-bleeding [48]. Increasing the operating temperature is a very effective means to improve $\mathrm{CO}$ tolerance of the PEFC, yet the upper temperature limit for MEAs that rely on the presence of water for proton transport is $100-120{ }^{\circ} \mathrm{C}$. There is still significant CO coverage of conventional $\mathrm{Pt}$ anode catalysts at these temperatures, which calls for improved catalysts with higher intrinsic $\mathrm{CO}$ tolerance. Until today, the most CO tolerant and durable electrocatalyst in fuel cell conditions is known to be Pt-Ru. The superior $\mathrm{CO}$ tolerance of $\mathrm{Pt}-\mathrm{Ru}$ over pure $\mathrm{Pt}$ is generally explained with a bi-functional mechanism, according to which the $\mathrm{CO}$ electrooxidation is promoted by formation adsorbed oxygen-containing species, $(\mathrm{OH})_{\text {ads }}$, on the oxophilic Ru surface [49][50]. Yet experimental and theoretical studies have also proven that equilibrium $\mathrm{CO}$ coverage on $\mathrm{Pt}-\mathrm{Ru}$ alloys is lower compared to pure Pt due to an electronic effect [51][52].

We have studied the $\mathrm{CO}$ tolerance of $\mathrm{Pt}$ and different types of Pt-Ru gas diffusion electrodes. Electrochemical impedance spectroscopy (EIS) has been used as an in situ technique for assessing the $\mathrm{CO}$ tolerance. The $\mathrm{CO}$ tolerance of the Pt-Ru electrodes varies substantially dependent on their exact formulation and morphology, i.e. structural and compositional properties of the carbon supported Pt-Ru catalyst and the electrode design. Furthermore, the ef- 

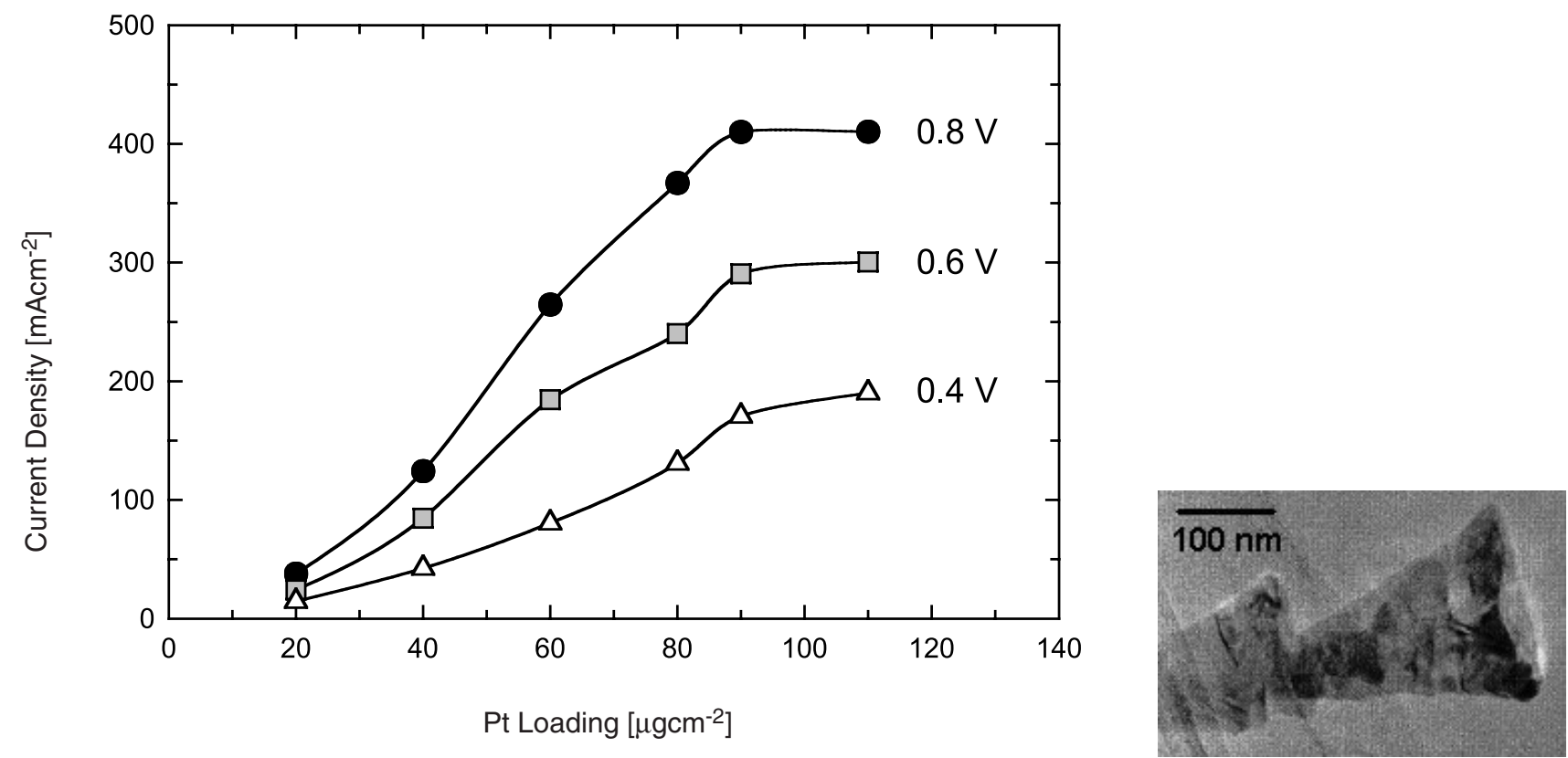

Fig. 8. Variation of current density with Pt loading at $+0.4 \mathrm{~V}, 0.6 \mathrm{~V}$ and $0.8 \mathrm{~V}$ vs. Ag/AgCl for Pt incorporated poly (3-methyl)thiophene (PMT) nanocone electrodes at room temperature. Current densities were measured from cyclic voltammograms run in $1 \mathrm{M} \mathrm{H}_{2} \mathrm{SO}_{4} / 1 \mathrm{M} \mathrm{CH}_{3} \mathrm{OH}$ between -0.2 and $+0.8 \mathrm{~V}$. Scan rate $50 \mathrm{mV} / \mathrm{s}$. Inset shows the TEM image of PMT nanocones.

fect of increasing cell temperature and $\mathrm{O}_{2}$ - or air-bleeding proved to be strongly dependent on the type and supplier of the selected electrode material. The effect of cell temperature on single cell performance using Pt and Pt$\mathrm{Ru}$ electrodes from two suppliers, E-TEK Inc. and Tanaka Kikinzoku International K.K, at a cell current density of 500 $\mathrm{mA} / \mathrm{cm}^{2}$ and standard cell components, i.e. cathode (Pt E-TEK, $0.6 \mathrm{mg}_{\mathrm{Pt}} / \mathrm{cm}^{2}$ ) and membrane (Nafion ${ }^{\circledR} 115$ ), has been compared (Fig. 9). The CO tolerance of the different anode electrodes increases in the order Pt E-TEK < Pt-Ru E-TEK (50:50) < Pt-Ru Tanaka (50:50) < Pt-Ru Tanaka (40:60). The Tanaka Pt-Ru electrodes exhibited a superior $\mathrm{CO}$ tolerance already at $80{ }^{\circ} \mathrm{C}$, even though the nominal catalyst loading is lower than that of the E-TEK electrodes. XPS analysis of the Pt-Ru electrodes indicated more alloyed $\mathrm{Pt}-\mathrm{Ru}$ and hydrous $\mathrm{Ru}$ oxides in the Tanaka electrodes. A lower CO coverage, $\theta_{\mathrm{CO}}$, and a higher $\mathrm{CO}$ oxidation rate, $k_{\mathrm{CO}}$, was obtained for the Tanaka electrodes from the fitting of experimental ac impedance spectra using a simple mathematical model (Table 2). Generally, the presence of $\mathrm{Ru}$ leads to an increased rate of formation of $(\mathrm{OH})_{\mathrm{ads}}$ on the catalyst surface, which is required to electrooxidize adsorbed CO. In addition to the electrocatalytic properties of the different Pt-Ru catalysts among each other and compared to Pt, the design of the electrode, i.e. the type of gas diffusion medium, composition and morphology of the microporous layer and the catalyst layer, has a significant influence on the $\mathrm{CO}$ tolerance in a PEFC [53].

\subsection{Co-Sputtering of Electro- chemically Active Materials}

Reducing the noble metal loading of the fuel cell electrodes is one of the crucial factors in making the fuel cell technology cost efficient and competitive to the traditional heat engines. Hence, the challenge is to find alternative methods that allow preparation of electrocatalyst material with low noble metal loading and high electrochemical ac- tivity. Sputtering is one of the alternative techniques; it has been recently described in literature [54][55]. The advantages of this technique compared to the wet chemical process are: elimination of chemicals, flexibility, and well-established system for recycling of metals. In all reported studies on sputtering related to fuel cell application, a continuous $\mathrm{Pt}$ film is deposited on a carbon-only gas diffusion electrode (GDE)

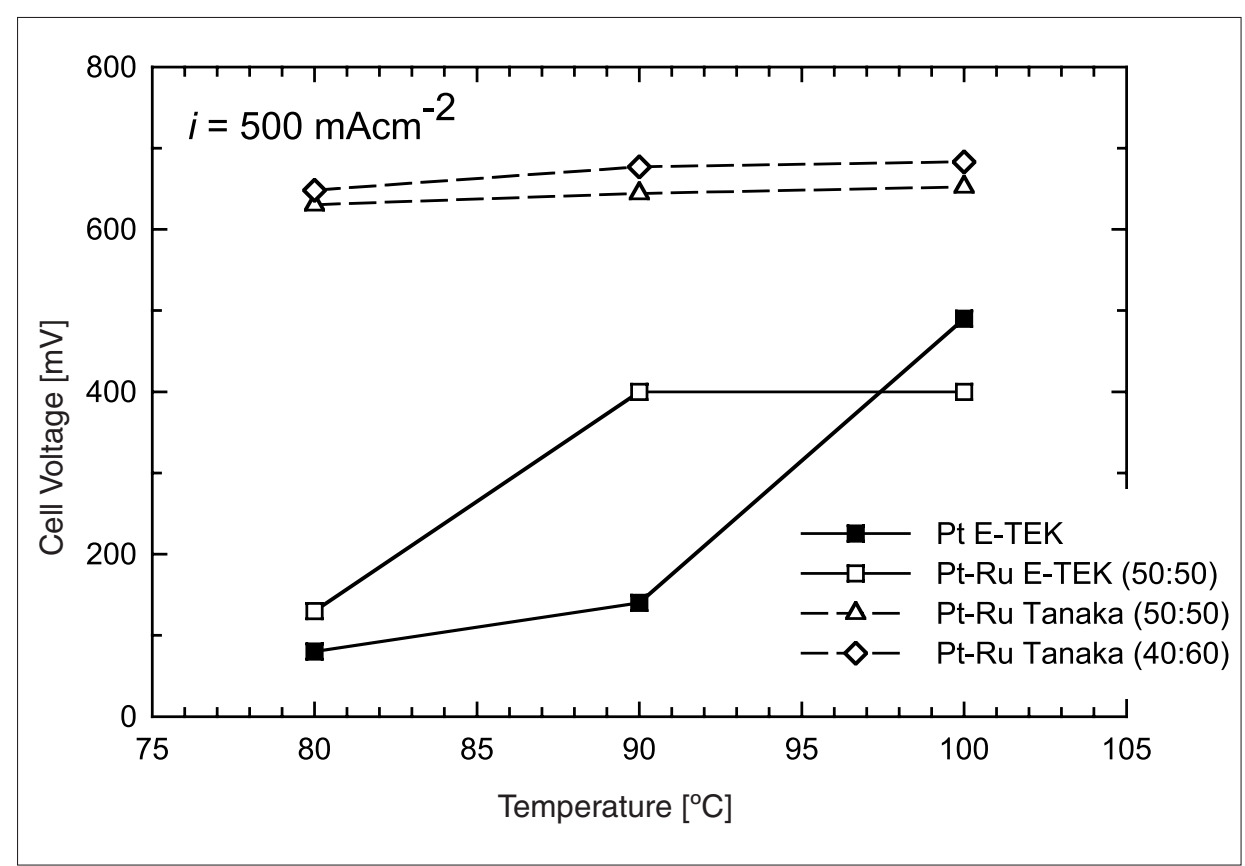

Fig. 9. Cell voltage as a function of temperature at a current density of $500 \mathrm{~mA} / \mathrm{cm}^{2}$ for MEAs with different anode electrodes. Membrane Nafion ${ }^{\circledR} 115$, cathode E-TEK $0.6 \mathrm{mg}_{\mathrm{Pt}} \mathrm{cm}^{-2} \cdot \mathrm{H}_{2} / 100 \mathrm{ppm} \mathrm{CO}$ was used as fuel and $\mathrm{O}_{2}$ as oxidant, both humidified at $95^{\circ} \mathrm{C}$, pressure $3 \mathrm{bar}_{\text {a. }}$. 
Table 2. Kinetic parameters characterizing the CO tolerance of different PEFC anodes, obtained from the fitting of ac impedance spectra $\left(T_{\text {cell }}=100^{\circ} \mathrm{C}\right)$.

$\begin{array}{lll}\text { Electrode } & \begin{array}{l}\text { CO coverage } \theta_{\text {CO }} \\ {[\%]}\end{array} & \begin{array}{l}\text { CO electrooxidation rate } k_{r}{ }_{r} \\ {\left[\mathrm{mmol} \mathrm{cm}^{-2} \mathrm{~s}^{-1}\right]}\end{array} \\ \text { E-TEK Pt } & 98 & 1.7 \cdot 10^{-6} \\ \text { E-TEK Pt-Ru } & 99 & 1.7 \cdot 10^{-6} \\ \text { Tanaka Pt-Ru(50:50) } & 65 & 1.3 \cdot 10^{-3} \\ \text { Tanaka Pt-Ru(40:60) } & 65 & 3.6 \cdot 10^{-3}\end{array}$

Table 3. Pt loading, roughness factor, $r_{f}$, and specific Pt surface area, $A_{s}$, for the Pt-film and the cosputtered Pt/C films.

\begin{tabular}{lccc} 
Sample & $\begin{array}{c}\text { Pt loading } \\
{\left[\mathrm{mg} / \mathrm{cm}^{2}\right]}\end{array}$ & $\begin{array}{c}\text { Roughness factor } r_{f} \\
{\left[\mathrm{~cm}^{2}{ }_{\mathrm{Pt}} / \mathrm{cm}^{2}{ }_{\text {geom. }}\right]}\end{array}$ & $\begin{array}{c}\text { Specific Pt surface area } A_{S} \\
{\left[\mathrm{~m}^{2} / \mathrm{g}\right]}\end{array}$ \\
\hline Co-sputtered Pt/C I & 0.207 & 23 & 11 \\
Co-sputtered Pt/C II & 0.468 & 128 & 27 \\
Co-sputtered Pt/C III & 1.288 & 193 & 15 \\
Pt-film & 0.060 & 4 & 7
\end{tabular}

or directly onto an electrolyte membrane [56]. A shortcoming of sputtering continuous films might be that a small catalytic active surface area will be obtained. A larger active surface area is expected when Pt and $\mathrm{C}$ are co-sputtered [57].

In this study, we have investigated the electrochemical activity and structural properties of co-sputtered $\mathrm{Pt} / \mathrm{C}$-films with different Pt-loadings on glassy carbon (GC) and Al-foil substrate. For this purpose, a number of techniques, i.e. cyclic voltammetry (CV), X-ray photoelectron spectroscopy (XPS), X-ray absorption spectroscopy (XAS), anomalous small angle $\mathrm{X}$-ray spectroscopy (ASAXS), and transmission electron microscopy (TEM), were employed. A graphite target with attached or embedded Pt wires or pellets, respectively, was used as sputtering target. The samples in the order of increasing Pt-loading are denoted I, II and III (Table 3). A high activity for $\mathrm{H}$-underpotential deposition on $\mathrm{Pt}$ was demonstrated for the co-sputtered samples, evidenced by CV. We observed that the surface roughness factor of the films increased with increasing Pt-loading. The experimental procedure and the analysis methods are described in detail elsewhere [53]. The specific active surface area of the samples, calculated by dividing the real active surface area by the Pt-loading obtained from XAS, proved to be highest for the $\mathrm{Pt} / \mathrm{C}$ sample II $\left(0.468 \mathrm{mg}_{\mathrm{Pt}} / \mathrm{cm}^{2}\right)$.

The size of the Pt particles increased with increasing Pt-loading, as evidenced by TEM, XPS, XAS, ASAXS. A columnar structure was evident from the TEM- and ASAXS-analyses for the selected sputter- ing condition in this study [58]. Further investigations on the electrochemical activity and stability of the co-sputtered films are in progress.

\subsection{Alternative Oxygen Reduction Catalysts}

In conventional PEFCs and DMFCs pure $\mathrm{Pt}$ is used as a cathode electrocatalyst. Due to its high price it is highly desirable to find less expensive materials. Although significant progress has been made, the performance of alternative catalysts is still limited due to various reasons, such as poor electrocatalytic reaction kinetics. The methanol crossover in DMFCs causes cathode depolarization and therefore performance losses. Methanol tolerant electrocatalysts studied for the oxygen reduction reaction (ORR) include $\mathrm{Pt}$ alloys with transition-metals [59], heat-treated metalloporphyrins [60], and Ru-based chalcogenides [61][62].

We are investigating alloys of Pt with transition metals, such as Pt-Ni and Pt-Co, and $\mathrm{Pt}$ containing metal oxides, particularly pyrochlores of the general formula $\mathrm{Bi}_{2} \mathrm{Pt}_{\mathrm{y}} \mathrm{Ir}_{2-\mathrm{y}} \mathrm{O}_{7}$. Catalytic activities of Pt-Ni and $\mathrm{Pt}-\mathrm{Co}$ alloys have been studied both by half-cell and fuel cell measurements.

Oxygen reduction kinetics of carbonsupported $\mathrm{Pt}$ alloyed with $\mathrm{Ni}$ or $\mathrm{Co}$ and smooth bulk electrodes have been studied in half-cell measurements in $0.1 \mathrm{M} \mathrm{HClO}_{4}$ at $20-60{ }^{\circ} \mathrm{C}$. Polycrystalline bulk electrodes of $\mathrm{Pt}$ alloyed with 25 at- $\% \mathrm{Ni}$ or 25 at-\% Co showed very similar behavior with a catalytic activity enhancement corresponding to a factor of 2 over bulk $\mathrm{Pt}$.
The same behavior was observed for supported catalysts. It was proposed that the kinetic enhancement is contained in the preexponential factor of the conventional transition state theory rate expression [63][64]. Fuel cell tests were performed in order to compare the catalytic activity of the Pt-Co and Pt gas diffusion cathodes. The comparison of the polarization curves based on nominal loading of Pt-Co and Pt cathodes showed that the activity for the ORR is comparable or even slightly higher for the Pt-Co cathode than for the Pt cathode [37].

The ORR activity and methanol tolerance of perovskites and pyrochlores have been evaluated in half-cell experiments in $0.5 \mathrm{M} \mathrm{H}_{2} \mathrm{SO}_{4}$ at $25{ }^{\circ} \mathrm{C}$ [65][66]. $\mathrm{Bi}_{2} \mathrm{Pt}_{\mathrm{y}} \mathrm{Ir}_{2-\mathrm{y}} \mathrm{O}_{7}$ electrodes were prepared by pressing the oxide powders into pellets followed by vacuum impregnation with epoxy in order to minimize the porosity. After a pre-treatment of potential cycling between $-0.6 \mathrm{~V}$ and $+0.6 \mathrm{~V}$ vs. $\mathrm{Hg} / \mathrm{Hg}_{2} \mathrm{SO}_{4}$, the ORR activity of $\mathrm{Bi}_{2} \mathrm{PtIrO}_{7}, \mathrm{Bi}_{2} \mathrm{Pt}_{07} \mathrm{Ir}_{13} \mathrm{O}_{7}$ and $\mathrm{Bi}_{2} \mathrm{Pt}_{0.6} \mathrm{Ir}_{1.4} \mathrm{O}_{7}$ pellets, operated as rotating disk electrodes, was measured and compared to a rotated polycrystalline bulk $\mathrm{Pt}$ disk electrode. The activity of $\mathrm{Bi}_{2} \mathrm{Pt}_{\mathrm{y}} \mathrm{Ir}_{2-\mathrm{y}} \mathrm{O}_{7}$ increases with increasing $\mathrm{Pt}(\mathrm{IV})$ content of the pyrochlore [67]. Since $\mathrm{Bi}_{2} \mathrm{Ir}_{2} \mathrm{O}_{7}$ is neither active towards oxygen reduction nor methanol oxidation, it appears that the $\mathrm{Pt}(\mathrm{IV})$ content in the structure has an influence on the methanol tolerance of the $\mathrm{Bi}_{2} \mathrm{Pt}_{\mathrm{y}} \mathrm{Ir}_{2-\mathrm{y}} \mathrm{O}_{7}$ pyrochlores. We found that $\mathrm{Bi}_{2} \mathrm{Pt}_{0.6} \mathrm{Ir}_{1.4} \mathrm{O}_{7}$ is an $\mathrm{O}_{2}$ reduction catalyst, which is essentially inactive towards methanol oxidation (Fig. 10). At a bulk Pt electrode, on the other hand, $\mathrm{O}_{2}$ reduction and methanol oxidation occur at the same time (dashed line). As a result, the convection-diffusion-limited current for $\mathrm{O}_{2}$ reduction is reached at a significantly more negative potential compared to a bulk Pt electrode in the absence of methanol (solid line). The demonstrated ORR activity and methanol tolerance of the pyrochlores with the general formula $\mathrm{Bi}_{2} \mathrm{Pt}_{\mathrm{y}} \mathrm{Ir}_{2-\mathrm{y}} \mathrm{O}_{7}$ suggests that these oxides may be interesting cathode catalyst materials for the DMFC. The balance between high ORR activity and low methanol oxidation activity is possible through optimization of the pyrochlore structure. Furthermore, the true nature of the catalytic active surface needs to be identified.

\section{Conclusion}

Scientific activities in Switzerland related to materials for the polymer electrolyte fuel cell (PEFC) and the direct methanol fuel cell (DMFC) are in different stages between fundamental and applied research and, to some extent, development. Some of the key materials challenges are addressed at the Paul Scherrer Institut (PSI) in Villi- 
gen $\mathrm{AG}$ and the École Polytechnique Fédérale de Lausanne (EPFL). In short, the requirements for the components of the membrane electrode assembly (MEA) are: functionality, durability, and cost.

Due to the low operating temperature (up to $120{ }^{\circ} \mathrm{C}$ maximum) of the PEFC/DMFC, expensive noble metals on the basis of Pt have to be used as electrocatalysts to promote the half-cell reactions on the fuel and air electrode, respectively. Maximizing the surface area and electrochemical activity of the catalyst is therefore an important field of activity. Using model electrodes and a well-defined electrochemical setup, it is found that the extent and stability of electrochemically active Pt surface strongly depends on the morphology of the material. In another aspect of the work, cosputtering of $\mathrm{Pt}$ and carbon is employed as an alternative method to prepare catalytically active materials. The Pt in co-sputtered $\mathrm{Pt} / \mathrm{C}$ has a higher specific surface area compared to pure sputtered Pt. In another study, promising methanol oxidation activity of catalytic systems based on Pt, Pt alloy and Pt transition metal oxides in combination with nanostructured carbon and conducting polymers has been achieved. In a study on electrode characterization, the tolerance of commercial anode electrocatalysts and electrodes towards $\mathrm{CO}$ in the $\mathrm{H}_{2}$ fuel stream is assessed using electrochemical impedance spectroscopy, which serves as a tool to determine critical kinetic parameters of the anode reaction using $\mathrm{H}_{2}$ with admixed $\mathrm{CO}$ at the ppm level as fuel. In a project on new catalysts for the oxygen reduction reaction, encouraging activity and methanol tolerance is found for Pt containing oxide materials in half-cell reactions.

The requirements for the proton exchange membrane can be broken down into specifications for conductivity, thickness, mechanical and chemical stability, and water management properties. PSI has been committed since 1992 to developing proton exchange membranes based on the method of radiation grafting, which is an intrinsically cost-effective technique. Substantial improvements and breakthroughs have been made since with respect to the properties of the membrane as well as the fabrication process. We have shown performance in the single cell comparable to Nafion ${ }^{\circledR}$ 112, and MEA durability exceeding 4000 $\mathrm{h}$ at a cell temperature of $80{ }^{\circ} \mathrm{C}$ at constant conditions. The versatility of radiation grafting lends itself to tailoring of the material for the use in the DMFC. Here, the methanol permeation from anode to cathode is detrimental to fuel and voltage efficiency. The PSI membrane shows lower methanol and water crossover compared to Nafion ${ }^{\circledR} 117$ without being detrimental to cell performance. In an attempt to promote the development of fluorine free membranes, polyarylene block copolymer membranes have been developed in collaboration with the Technical University Munich. They have excellent stress-strain properties, conductivity identical to Nafion ${ }^{\circledR}$, and show promising fuel cell performance and stability.

Received: September 19, 2004

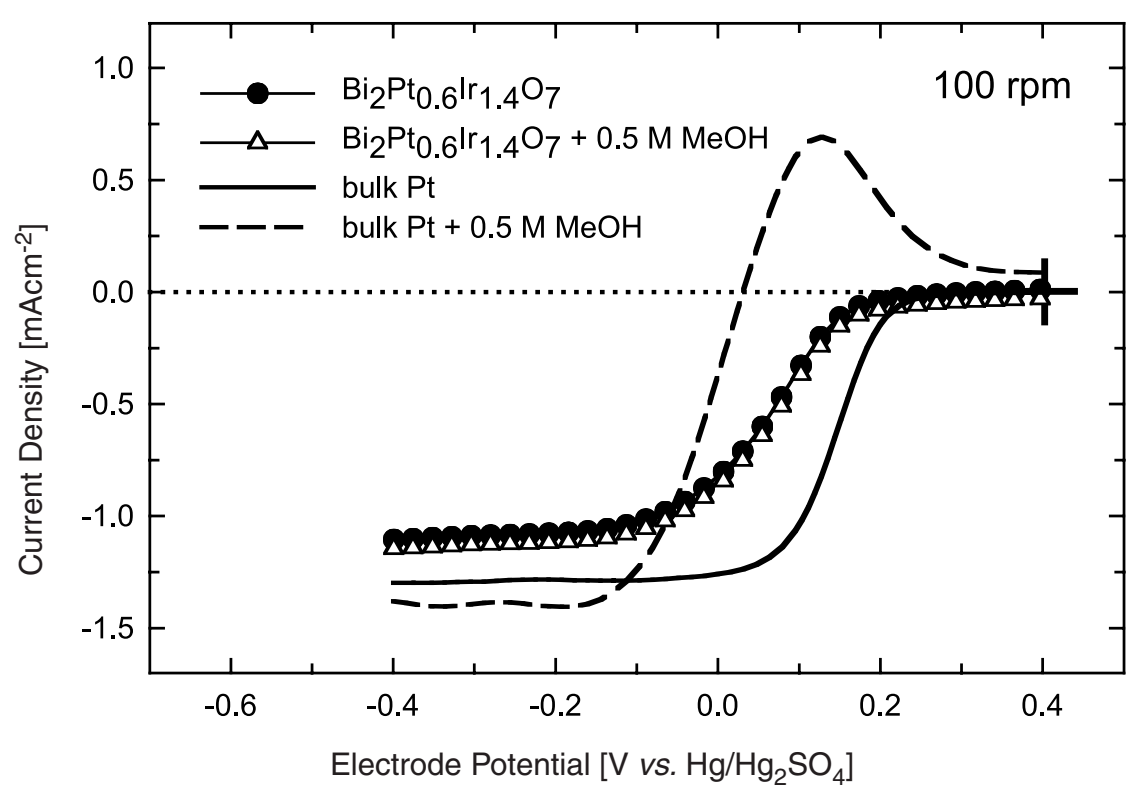

Fig. 10. Current-potential curves for the reduction of $\mathrm{O}_{2}$ on a $\mathrm{Bi}_{2} \mathrm{Pt}_{0.6} \mathrm{Ir}_{1.4} \mathrm{O}_{7}$ pellet electrode, operated as rotating disk electrode, compared to a rotated polycrystalline bulk Pt disk electrode in $\mathrm{O}_{2}$ saturated $0.5 \mathrm{M} \mathrm{H}_{2} \mathrm{SO}_{4}$ at $25{ }^{\circ} \mathrm{C}$ in the presence and absence of $0.5 \mathrm{M}$ methanol. Rotation rate= $100 \mathrm{rpm}$. Scan rate $=5 \mathrm{mV} / \mathrm{s}$.
[1] J. Van herle, A. Schuler, L. Dammann, M. Bosco, T.-B. Truong, E. De Boni, F. Hajbolouri, F. Vogel, G.G. Scherer Chimia, 2004, 58,887

[2] A. Chapiró, Radiat. Phys. Chem. 1977, 9 , 55.

[3] V.S. Ivanov, 'Radiation Chemistry of Polymers', VSP, Utrecht, 1992.

[4] L. Steuernagel, D.E. Kaufmann, A. Wokaun, G.G. Scherer, H.P. Brack, PSI Scientific Report/Volume V - General Energy 2002, ISSN 1423-7342, 77.

[5] M. Slaski, G.G. Scherer, A. Wokaun, unpublished results 2004.

[6] H.P. Brack, H.G. Bührer, L. Bonorand, G.G. Scherer, J. Mater. Chem. 2000, 10, 1795.

[7] A. Chapiró, 'Radiation Chemistry of Polymeric Systems', Wiley, New York, 1962.

[8] T. Rager, Helv. Chim. Acta 2003, 86, 1966.

[9] B. Gupta, G.G. Scherer, Chimia 1994, 48, 127.

[10] B. Gupta, F.N. Büchi, G.G. Scherer, J. Polym. Sci., Polym. Chem. 1994, 32, 1931.

[11] H.P. Brack, G.G. Scherer, Macromol. Symp. 1997, 126, 25.

[12] H.P. Brack, M. Wyler, M. Slaski, G. Peter, G.G. Scherer, Proc. 2nd European PEFC Forum, Ed. D. Stolten, B. Emonts, R. Peters, Lucerne, Switzerland, ISBN 3905592-13-4, June 30-July 4, 2003, 117.

[13] L. Gubler, H. Kuhn, T.J. Schmidt, G.G. Scherer, H.P. Brack, K. Simbeck, Fuel Cells 2004, 4, 196.

[14] T.R. Dargaville, G.A. George, D.J.T. Hill, A.K. Whittaker, Progr. Polym. Sci. 2003, 28,1355

[15] F.N. Büchi, B. Gupta, O. Haas, G.G. Scherer, Electrochim. Acta 1995, 40, 345.

[16] J. Huslage, T. Rager, B. Schnyder, A. Tsukada, Electrochim. Acta 2002, 48, 247.

[17] H.P. Brack, F.N. Büchi, J. Huslage, G.G. Scherer, Proceedings of the 2nd Symposium on Proton Conducting Membrane Fuel Cells II, Proceedings Volume 98-27, Ed. S. Gottesfeld, T.F. Fuller, The Electrochemical Society, Boston, USA, Nov 1-6, 1998, 52.

[18] H.P. Brack, M. Slaski, L. Gubler, G.G Scherer, S. Alkan, A. Wokaun, Fuel Cells 2004, 4, 141.

[19] B. Schnyder, T. Rager, R. Kötz, G.G. Scherer, submitted.

[20] H.P. Brack, D. Fischer, G. Peter, M. Slaski, G.G. Scherer, J. Polym. Sci. Part A: Polym. Chem. 2004, 42, 59.

[21] H.P. Brack, L. Gubler, G.G. Scherer (Paul Scherrer Institut), EP 03021 845.7, 2003.

[22] H.P. Brack, F.N. Büchi, J. Huslage, M. Rota, G.G. Scherer, ACS Symposium Series 744, Ed. I. Pinnau, B.D. Freeman, American Chemical Society, 2000, 174.

[23] J. Huslage, T. Rager, T.J. Schmidt, G.G. Scherer, PSI Scientific Report/Volume VGeneral Energy 2001, ISSN 1423-7342, 96.

[24] A.B. Geiger, T. Rager, L. Matejcek, G.G. Scherer, A. Wokaun, Proc. 1st European 
PEFC Forum, Ed. F.N. Büchi, G.G. Scherer, A. Wokaun, Lucerne, Switzerland, ISBN 3-905592-08-8, July 2-6, 2001, 129.

[25] A.B. Geiger, 'Characterization and Development of Direct Methanol Fuel Cells', ETH Dissertation Nr. 14872, 2002.

[26] D. Kramer, A.J. McEvoy, I. Schneider, H. Kuhn, A. Wokaun, G.G. Scherer, Chimia, 2004, 58,851

[27] C.K. Shin, G. Maier, G.G. Scherer, J. Mem. Sci. 2004, 245, 163.

[28] C.K. Shin, G. Maier, B. Andreaus, G.G. Scherer, J. Mem. Sci. 2004, 245, 147.

[29] M.W. Staub, 'Untersuchungen zur Grenzfläche Elektrode/Polymerelektrolyt in der Polymerelektrolyt-Brennstoffzelle', ETH Dissertation Nr. 11285, 1996.

[30] G.G. Scherer, Solid State Ionics 1997, 94, 249.

[31] Z. Veziridis, 'Modifizierung und Charakterisierung von Modellelektroden zur Optimierung elektrokatalytischer Vorgänge in der Polymerelektrolyt Brennstoffzelle', ETH Dissertation Nr. 13397, 1999.

[32] B. Steiger, G.G. Scherer, PSI Scientific Report/Volume V - General Energy 2001, ISSN 1423-7342, 101.

[33] Z. Veziridis, G.G. Scherer, E. Deiss, H. Freimuth, in 'Elektrochemische Reaktionstechnik und Synthese', Ed. J. Russow, G. Sandstede, R. Staab, Jahrestagung der GDChFachgruppe Angewandte Elektrochemie, Frankfurt am Main, 1998, 544.

[34] U.A. Paulus, Z. Veziridis, B. Schnyder, M. Kuhnke, G.G. Scherer, A. Wokaun, J. Electroanal. Chem. 2003, 541, 77.

[35] M. Kuhnke, T. Lippert, E. Ortelli, G.G. Scherer, A. Wokaun, Thin Solid Films 2004, 36, 453 .

[36] S. Stucki, R. Menth, Proc. Symp. 'Industrial Water Electrolysis', Spring Meeting of the Electrochemical Society, Ed. S. Srinivasan, F.J. Salzano, A.R. Landgrebe, Seattle, USA, May 21-26, 1978, 180.

[37] U.A. Paulus, 'Electrocatalysis for Polymer Electrolyte Fuel Cells: Metal Alloys and Model Systems', ETH Dissertation Nr. 14795, 2002.

[38] B. Steiger, G.G. Scherer, unpublished results, Paul Scherrer Institut, 2003.
[39] A. Reiner, B. Steiger, G.G. Scherer, A. Wokaun, PSI Scientific Report/Volume V-General Energy 2003, ISSN 1423-7342, 96.

[40] B. Rajesh, K.R. Thampi, J.M. Bonard, N. Xanthopoulos, H.J. Mathieu, B. Viswanathan, J. Mater. Chem. 2000, 10, 1757.

[41] B. Rajesh, K.R. Thampi, J.M. Bonard, N. Xanthopoulos, H.J. Mathieu, B. Viswanathan, J. Phys. Chem. B 2003, 107, 2701.

[42] B. Rajesh, V. Karthik, S. Karthikeyan, K.R. Thampi, J.M. Bonard, N. Xanthopoulos, H.J. Mathieu, B. Viswanathan, Fuel 2002, 81, 2177.

[43] B. Rajesh, K.R. Thampi, J.M. Bonard, N. Xanthopoulos, H.J. Mathieu, B. Viswanathan, Electrochem. Solid-State Lett. 2002, 5, E 71.

[44] B. Rajesh, K.R. Thampi, J.M. Bonard, N. Xanthopoulos, H.J. Mathieu, B. Viswanathan, Chem. Comm. 2003, 2022.

[45] B. Rajesh, K.R. Thampi, J.M. Bonard, A.J. McEvoy, N. Xanthopoulos, H.J. Mathieu, B. Viswanathan, J. Power Sources 2004, 133, 155.

[46] F. Hajbolouri, B. Andreaus, G.G. Scherer, A. Wokaun, Fuel Cells 2004, 4, 160.

[47] F. Hajbolouri, B. Andreaus, G.G. Scherer, A. Wokaun, Proceedings Volume '2002 Fuel Cell Seminar', Palm Springs, USA, Nov 18-21, 2002, 251.

[48] L. Gubler, G.G. Scherer, A. Wokaun, Phys. Chem. Chem. Phys. 2001, 3, 325.

[49] M. Watanabe, S. Motoo, Electroanal. Chem. Interf. Electrochem. 1975, 60, 267.

[50] N.M. Markovic, P.N. Ross, Surf. Sci. Rep. 2002, 45, 117

[51] J. McBreen, S. Mukerjee, J. Electrochem. Soc. 1995, 142, 3399.

[52] E. Christoffersen, P. Liu, A. Ruban, H.L. Skriver, J.K. Noerskov, J. Catal. 2001, 199, 123.

[53] F. Hajbolouri, 'Polymer Electrolyte Fuel Cells: Contributions to the Understanding of CO Tolerance', ETH Dissertation Nr. 15525, 2004.

[54] O. Enea, M. Rafai, A. Naudon, Ultramicroscopy 1992, 42-44, 572.

[55] E.A. Ticianelli, C.R. Derouin, S. Srinivasan, J. Electroanal. Chem. 1988, 251, 275.

[56] S. Hirano, J. Kim, S. Srinivasan, Electrochim. Acta 1997, 42, 1587.
[57] F. Hajbolouri, G.G. Scherer, T. Vad, B. Schnyder, S. Abolhassani-Dadras, M. Horisberger, A. Wokaun, PSI Scientific Report/Volume $V$ - General Energy 2003, ISSN 1423-7342, 87.

[58] T. Vad, F. Hajbolouri, H.G. Haubold, G.G. Scherer, A. Wokaun, Phys. Chem. B 2004, 108, 12442.

[59] E. Antolini, J. Appl. Electrochem. 2004, 34, 563.

[60] R. Jiang, D. Chu, J. Electrochem. Soc 2000, 147, 4605.

[61] N. Alonso-Vante, P. Bogdanoff, H. Tributsch, J. Catal. 2000, 190, 240.

[62] T.J. Schmidt, U.A. Paulus, H.A. Gasteiger, N. Alonso-Vante, R.J. Behm, J. Electrochem. Soc. 2000, 147, 2620.

[63] U.A. Paulus, A. Wokaun, G.G. Scherer, T.J. Schmidt, V. Stamenkovic, N.M. Markovic, P.N. Ross, Electrochim. Acta 2002, 47, 3787.

[64] U.A. Paulus, A. Wokaun, G.G. Scherer, T.J. Schmidt, V. Stamenkovic, V. Radmilovic, N.M. Markovic, P.N. Ross, J. Phys. Chem. B 2002, 106, 4181.

[65] N. Lempola, B. Steiger, T.J. Schmidt, G.G. Scherer, A. Wokaun, PSI Scientific Report/Volume V - General Energy 2002, ISSN 1423-7342, 84.

[66] N. Lempola, B. Steiger, G.G. Scherer, A. Wokaun, Proc. 2nd European PEFC Forum, Ed. D. Stolten, B. Emonts, R. Peters, Lucerne, Switzerland, ISBN 3-90559213-4, June 30-July 4, 2003, 407.

[67] N. Lempola, B. Steiger, G.G. Scherer, A. Wokaun, PSI Scientific Report/Volume VGeneral Energy 2003, ISSN 1423-7342, 98. 